\title{
Histological features of eosinophilic esophagitis in children and adolescents
}

\author{
Adriana Elisabeth Aguiar Benavides CARRASC ${ }^{1}$, Rodrigo Strehl MACHADO'1, \\ Francy Reis da Silva PATRÍCIO² and Elisabete KAWAKAMI ${ }^{1}$
}

ABSTRACT - Background - Eosinophilic esophagitis is an emerging disease featured by eosinophilic esophageal infiltrate not responsive to proton pump inhibitors. Objective - To characterize histological features of children and adolescents with eosinophilic esophagitis. Methods - Cross-sectional study in a tertiary hospital. Biopsies from each esophageal third from 14 patients (median age 7 years) with eosinophilic esophagitis were evaluated. Histological features evaluated included morphometry of esophageal epithelium, esophageal density (per high power field), extracellular eosinophilic granules, eosinophilic microabscesses, surface disposition of eosinophils, epithelial desquamation, peripapillary eosinophilia, basal layer hyperplasia and papillary elongation. Results - Several patients presented a normal esophageal macroscopy in the upper digestive endoscopy (6, 42.8\%), and the most common abnormality were vertical lines $(7,50 \%)$ and whitish spots over esophageal mucosa $(7,50 \%)$. Basal layer hyperplasia was observed in $88.8 \%$, $100 \%$ e $80 \%$ of biopsies from proximal, middle and lower esophagus, respectively $(P=0.22)$. Esophageal density ranges from 0 to more than 50 per hpf. Extracellular eosinophilic granules (70\%-100\%), surface disposition of eosinophils (60\%-93\%), epithelial desquamation $(60 \%-100 \%)$, peripapillary eosinophilia (70\%-80\%) were common, but evenly distributed among each esophageal third. Just one patient did not present eosinophils in the lower third, four in the middle third and four in the upper esophageal third. Conclusion - In the absence of hypereosinophilia, other histological features are present in eosinophilic esophagitis and may contribute to diagnosis. Eosinophilic infiltrate is focal, therefore multiple biopsies are needed for diagnosis. HEADINGS - Esophageal diseases. Abdominal pain. Eosinophilic esophagitis. Eosinophils. Peptic esophagitis.

\section{INTRODUCTION}

Eosinophilic esophagitis (EoE) is a chronic immunologic antigen-mediated disease associated with esophageal dysfunction and predominantly eosinophilic inflammation ${ }^{(12)}$. Overall prevalence has been estimated 1:10000, with 1:2500 incidence in developed countries $^{(11,20)}$. Although the incidence has been increasing in the last years, the disease is still regarded uncommon (9). However, there has been an increasing number of published papers on the subject since its first consensus report was held, in 2007 (FIGERS, First International Gastrointestinal Eosinophil Research Symposium), and $\mathrm{EoE}$ is regarded an emerging condition ${ }^{(8)}$.

Even though, increased recognition of EoE may occur due to increasing prevalence, as well as heightened clinical awareness ${ }^{(21)}$, the disease may still be underdiagnosed. The clinical manifestations are subtle and nonspecific in early childhood, and even in older patients, its symptoms and endoscopic features overlap with gastroesophageal reflux disease (GERD). Furthermore, the number and the location of esophageal biopsies needed for accurate diagnosis is still not well established. Moreover, the clinical relevance of other histologic features beyond eosinophils density is not well understood ${ }^{(2)}$. Finally, there is no prospective histopathologic study in pediatric patients with EoE in our country. Therefore, we designed this study to characterize histopathologic features of children with EoE.

\section{METHODS}

We prospectively evaluated 14 patients $(11 \mathrm{M} / 3 \mathrm{~F}$, median age 7 years, range: 1-14 years) with EoE in a 3-year period in the Pediatric Gastroenterology Outpatient Unit of Hospital São Paulo - University Hospital.

EoE was diagnosed by the presence of upper gastrointestinal symptoms associated with significant eosinophilic infiltrate $(>15$ per hpf in the most representative high power field) in esophageal biopsies, and no evidence of gastroesophageal reflux disease (GERD) and/or eosinophilic gastroenteropathy, according to consensus criteria established in the FIGERS, $2007^{(8)}$. GERD was excluded by a normal esophageal $\mathrm{pH}$ study and/or no clinical improvement after high-dose proton pump inhibitor (PPI) trial. The study was approved by the Institutional Review Board (Comitê de Ética em Pesquisa da EPM/UNIFESP, 1256/08). All parents were invited to participate in the study and signed an informed consent form.

The study included endoscopic esophageal biopsies taken during the primary endoscopy which lead to the diagnosis of EoE. The index endoscopy was performed in the university hospital in 10 patients, while it was performed in a different hospital in 4 patients.

\section{Histological evaluation}

Multiple esophageal biopsies were taken from distal, middle and proximal (2-3 from each site) in all patients except those who

\footnotetext{
Declared conflict of interest of all authors: none

Disclosure of funding: no funding received

${ }^{1}$ Disciplina de Gastroenterologia Pediátrica, Departamento de Pediatria, Escola Paulista de Medicina, Universidade Federal de São Paulo, São Paulo, SP, Brasil; ${ }^{2}$ Departamento de Patologia, Escola Paulista de Medicina, Universidade Federal de São Paulo, São Paulo, SP, Brasil.

Correspondence: Rodrigo Strehl Machado. Divisão de Gastroenterologia Pediátrica, Departamento de Pediatria, Escola Paulista de Medicina, Universidade Federal de São Paulo. Rua Cel Lisboa 826, Vila Clementino - CEP: 04020-041 - São Paulo, SP, Brasil. E-mail: rodrigo.strehl@gmail.com
} 
collected the specimens in an external hospital. Those four patients had only biopsies taken from distal esophagus. All patients had also biopsies taken from antrum and duodenum to rule out eosinophilic gastroenteritis.

Specimens were fixed in $10 \%$ formalin, included in paraffin tissue block, sectioned (5-6 $\mu \mathrm{m}$ thickness) and then stained (hematoxilin/eosin and periodic acid-Schiff (PAS)). Eosinophil density was reported from the most representative area, i.e. the area with higher eosinophil density, as eosinophil per high-power field (hdp). The high power field $\left(0.24 \mathrm{~mm}^{2}\right)$ was evaluated with $10 \mathrm{x}$ ocular and $40 \mathrm{x}$ objective lens ${ }^{(22)}$. Eosinophil density higher than 50 cells/hpf were regarded uncountable ${ }^{(8)}$. Eosinophilic microabcess was defined as a cluster of more than four intact eosinophils. Besides, extracellular eosinophilic granules, superficial layering of eosinophils, epithelial desquamation, peripapillary eosinophilia, presence of eosinophils in the lamina propria, basal cell hyperplasia and elongation of papillae were also noted.

Histometric analysis was performed with periodic acid-Shiff (PAS) stain. Total epithelial thickness and basal cell layer thickness were measured with the software ImageToll 3.0 for Windows (University of Texas Health Science Center at San Antonio, USA). Basal cell layer boundary was defined by the level in which nuclei were apart from each other by a distance of at least one nucleus. Basal cell hyperplasia was defined as more than $25 \%$ of epithelial thickness corresponding to basal cells layer, while elongated papillae were defined as papillae extending for more than $75 \%$ of epithelial thickness ${ }^{(17)}$. Finally, gastric specimens were evaluated for Helicobacter pylori infection with modified Giemsa stain.

Esophageal morphometric data were compared with historical pediatric data collected from patients with reflux esophagitis, previously published by our research group ${ }^{(13)}$. Specimens from those patients were evaluated by the same pathologist (FRSP).

\section{Statistics}

Qualitative variables were described by proportions, while quantitative variables were described by median and range, unless otherwise specified. Moreover, histometric data were reported by their mean and its 95\% confidence interval. Dichotomic histological data from each third (distal, middle and proximal) of esophagus were compared with Cochran's Q Test and Mc Nemar Test, while quantitative histological variables (papillae length, thickness of basal layer) were compared with Friedman's Test. Mann Whitney U test was used to compare histological features and patient's age group (younger and older than median). A $P$ value less than 0.05 was regarded significant.

\section{RESULTS}

\section{Clinical features}

The most common symptoms were abdominal pain $(78.6 \%)$, vomiting (50\%), regurgitation $(50 \%)$ and dysphagia $(50 \%)(\mathrm{Ta}-$ ble 1). Personal history of atopy was reported by $12 / 14(85.7 \%)$ patients, mostly allergic rhinitis $(85.7 \%)$. Among food allergies, the most common allergenic food was cow's milk (6/7, 85.7\%), soy $(1 / 7,14.3 \%)$ and shrimp $(1 / 7,14.3 \%)$. Familial history of allergic disease was present in $9 / 14(64.3 \%)$ patients. Two patients were siblings.

The first endoscopy was requested due to reflux symptoms in $10 / 14(71.4 \%)$, while in 2 was due to food allergy $(2 / 14,14.3 \%)$ and dysphagia $(2 / 14,14.3 \%)$. The exam was normal in $43 \%$ (Table 1$)$.
TABLE 1. Demographic, clinical and endoscopic features of 14 patients with eosinophilic esophagitis

\begin{tabular}{|c|c|c|}
\hline Variable & $\mathbf{N}$ & $(\%)$ \\
\hline Age, years (median, range) & $7(1-14)$ & \\
\hline \multicolumn{3}{|l|}{ Sex } \\
\hline Male & 11 & 78.6 \\
\hline \multicolumn{3}{|l|}{ Symptoms } \\
\hline Abdominal pain & 11 & 78.6 \\
\hline Vomiting & 7 & 50.0 \\
\hline Regurgitation & 7 & 50.0 \\
\hline Dysphagia & 7 & 50.0 \\
\hline Failure to thrive & 6 & 42.8 \\
\hline Thoracic pain & 3 & 21.4 \\
\hline Food impaction & 3 & 21.4 \\
\hline \multicolumn{3}{|l|}{ Atopic comorbidities } \\
\hline Food allergy & 12 & 85.7 \\
\hline Allergic rhinitis & 7 & 50.0 \\
\hline Asthma & 6 & 42.8 \\
\hline Dermatitis & 4 & 28.6 \\
\hline \multicolumn{3}{|l|}{ Familial history of atopy } \\
\hline Asthma & 9 & 64.3 \\
\hline Rhinitis & 12 & 85.7 \\
\hline \multicolumn{3}{|l|}{ Endoscopic features } \\
\hline Normal & 6 & 42.8 \\
\hline Vertical lines & 7 & 50.0 \\
\hline White spots & 7 & 50.0 \\
\hline Edema & 3 & 21.4 \\
\hline Friability & 3 & 21.4 \\
\hline Erosion & 2 & 14.3 \\
\hline Stricture & 1 & 7.1 \\
\hline Trachealization & 1 & 7.1 \\
\hline
\end{tabular}

\section{Histological features}

Eosinophil density ranged from zero to uncountable (i.e. more than 50 cells/hpf) in all biopsies $(n=34)$. The median count was 28 cells/hpf in the proximal third, 18 cells/hpf in the middle third and uncountable in the distal third (Table 2). The eosinophil count was less than 15 cells/hpf in $9 / 34(26.5 \%)$ biopsies. There was no relationship between age and eosinophil count. Eosinophils were observed in the lamina propria of most tissue samples, except one from the proximal esophagus. Most patients presented eosinophilic microabscesses (Table 3, Figure 1, Figure 2). One patient presented $H$. pylori infection in the gastric mucosa - this patient presented chronic active gastritis without significant eosinophilia.

Morphometric evaluation was possible in 26/30 biopsies. In Table 4, morphometric data from patients with EoE are compared with those from patients with reflux esophagitis reported in a previously published study by our group ${ }^{(10)}$. Data are reported as mean and $95 \%$ confidence interval in both groups. It is noteworthy that there is no overlap between $95 \%$ confidence interval of both absolute mean thickness of basal layer and relative thickness of basal layer (percentage of total epithelial thickness), with patients with EoE presenting larger figures than those previously reported with reflux esophagitis. 
TABLE 2. Eosinophils count per high power field from 10 patients with biopsies collected from each esophageal third

\begin{tabular}{lccc}
\hline Patient & $\begin{array}{c}\text { Proximal } \\
\text { esophagus }\end{array}$ & $\begin{array}{c}\text { Middle } \\
\text { esophagus }\end{array}$ & $\begin{array}{c}\text { Distal } \\
\text { esophagus }\end{array}$ \\
\hline 1 & 28 & $>50$ & 16 \\
2 & 12 & 33 & $>50$ \\
4 & 2 & 20 & 25 \\
5 & 0 & 0 & 22 \\
6 & 5 & 0 & $>50$ \\
9 & $>50$ & 5 & $>50$ \\
10 & $>50$ & 7 & 7 \\
11 & $>50$ & 18 & 20 \\
12 & $>50$ & $>50$ & $>50$ \\
14 & $>50$ & $>50$ & $>50$ \\
\hline
\end{tabular}

TABLE 3. Histological findings in esophageal fragments in patients with eosinophilic esophagitis

\begin{tabular}{lcccc}
\hline Esophageal third & $\begin{array}{c}\text { Proximal } \\
\text { n(\%) }\end{array}$ & $\begin{array}{c}\text { Middle } \\
\text { n (\%) }\end{array}$ & $\begin{array}{c}\text { Distal } \\
\text { n (\%) }\end{array}$ & P-value* \\
\hline $\begin{array}{l}\text { Eosinophilic } \\
\text { microabscesses }\end{array}$ & $08(80)$ & $05(50)$ & $07(50)$ & 0.55 \\
$\begin{array}{l}\text { Extracellular } \\
\text { eosinophilic } \\
\text { granules }\end{array}$ & $07(70)$ & $08(80)$ & $14(100)$ & 0.1 \\
$\begin{array}{l}\text { Superficial layering } \\
\text { of eosinophils }\end{array}$ & $06(60)$ & $09(90)$ & $13(93)$ & 0.17 \\
$\begin{array}{l}\text { Epithelial } \\
\text { desquamation }\end{array}$ & $06(60)$ & $08(80)$ & $14(100)$ & 0.25 \\
$\begin{array}{l}\text { Peripapillary } \\
\text { eosinophilia }\end{array}$ & $07(70)$ & $08(80)$ & $11(78.5)$ & 0.78 \\
\hline
\end{tabular}

* Cochran's Q-test.

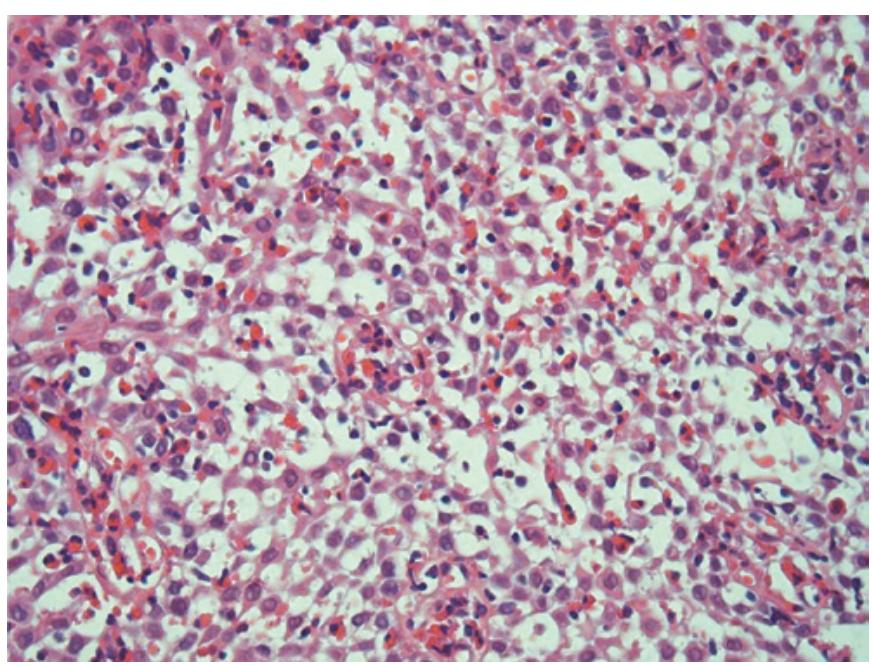

FIGURE 1. Photomicrography, hematoxylin-eosin stain, $400 \mathrm{X}$. Representative of eosinophilic esophagitis. Intense infiltrate of eosinophils, extracellular eosinophilic granules and eosinophilic microabscesses.

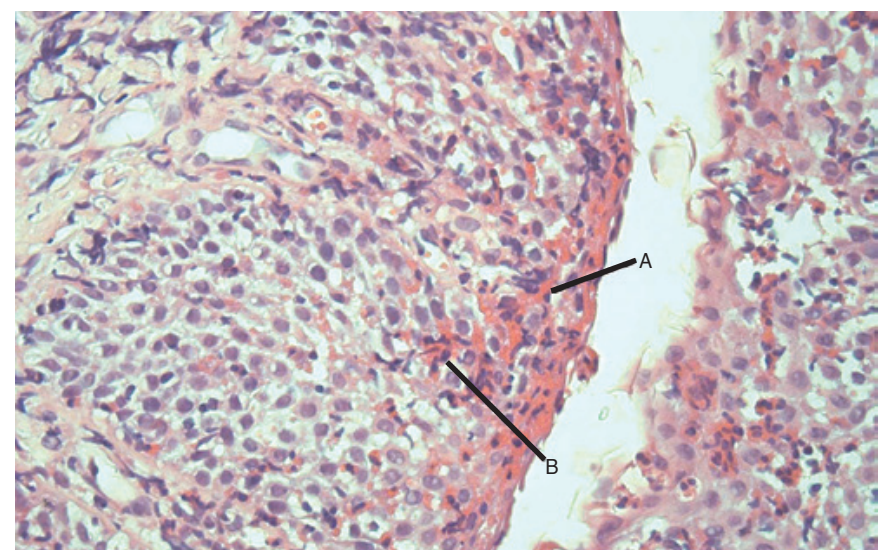

FIGURE 2. Photomicrography, hematoxylin-eosin stain, $400 \mathrm{X}$. Representative of eosinophilic esophagitis. A. Superficial layering of eosinophils. B. Eosinophilic microabscesses.

TABLE 4. Histometric data (mean and $95 \%$ confidence interval) from distal esophageal biopsies of patients with eosinophilic esophagitis and reflux esophagitis

\begin{tabular}{lcc}
$\begin{array}{l}\text { Histometric } \\
\text { parameter }\end{array}$ & $\begin{array}{c}\text { Eosinophilic esophagitis } \\
(\mathbf{n}=14) \\
\text { Mean }(95 \% \mathrm{CI})\end{array}$ & $\begin{array}{c}\text { Reflux esophagitis } \\
(\mathbf{n}=26) \\
\text { Mean }(95 \% \mathrm{CI})\end{array}$ \\
\hline $\begin{array}{l}\text { Thickness of } \\
\text { basal layer }(\mu \mathrm{m})\end{array}$ & 160.35 & 55.81 \\
& $(72.6-248.1)$ & $(49.96-61.66)$ \\
$\begin{array}{l}\text { Thickness of } \\
\text { basal layer }(\%)\end{array}$ & 48.61 & $\begin{array}{c}21.68 \\
(29.21-68.01)\end{array}$ \\
\hline
\end{tabular}

\section{DISCUSSION}

We enrolled 14 patients in a single center (average 4.5 patients per year of study), and that figure is less than our initial expectations. However, the observed prevalence may be close to the real one, as the disease is still uncommon. In another study from our citye' authors reported just one patient with more than 20 eosinophils per hpf among 103 patients with reflux symptoms refractory to clinical treatment with proton pump inhibitor (PPI). The prevalence of EoE varies geographically. Spergel et al. ${ }^{(27)}$ reported on a much larger number of pediatric patients in USA (562 patients in 14 years, 40 patients/year).

Endoscopic features are not specific and $43 \%$ of our patients presented a normal upper endoscopy. Therefore, the diagnosis depends on histological evaluation of esophageal mucosa. The most intense eosinophilic infiltrate was seen in the distal esophagus, as reported by other authors ${ }^{(10,20)}$. Pinheiro et al. ${ }^{(19)}$ reported a series of 11 patients with EoE, all of them presenting more than 30 eosinophils/hpf in distal esophagus. The more intense infiltrate observed by those authors may be a consequence of different inclusion criteria ${ }^{(12)}$. Also, they evaluated just the distal esophagus, while one of our patients had normal distal esophagus, suggesting that proximal biopsies are required to ensure proper sensitivity. Of course, the present study reports on a small sample size, but another study has shown that $3 \%$ of patients would have missed the diagnosis if only biopsies from distal esophagus had been taken ${ }^{(26)}$. In the present study, we collected 2-3 fragments from each third, and 9/34 biopsies did not meet the diagnostic criteria. 
The clinical features described by our study are similar to those reported elsewhere, with predominance of males $(78.6 \%)$, as well as frequent abdominal pain, vomiting, failure to thrive and regurgitation, symptoms that resemble gastroesophageal reflux disease $(\text { GERD })^{(11,27)}$. Furthermore, EoE is a immunologically-mediated disease, and most patients present evidence of food allergy and/or atopy ${ }^{(7,24)}$. In the present study, $85.7 \%$ had history of atopy, more than the $68 \%$ that was reported elsewhere ${ }^{(27)}$.

Genetic susceptibility may play a role. Rothenberg et al. associated a gene locus (5q22) to the disease ${ }^{(23,24)}$. In our study, two patients were from the same family. Another group, reported that familial history of EoE occurs in $6.8 \%$ of patients. In that study, the disease occurred in six twins as well as in a mother of a patient ${ }^{(16)}$.

Nowadays, the main concept guiding the clinical management of eosinophilic esophagitis is treating to target. The target is the generally expressed as less than 15 eosinophils/hpf, but authors have reported that diminishing the basal cell hyperplasia may be an important target also ${ }^{(5)}$. Basal cell hyperplasia is a histological feature that is shared with reflux esophagitis ${ }^{(9)}$, although it may be more intense in the $\mathrm{EoE}^{(1,28)}$.

There is need for more specific markers of this disease. Eosinophilic microabscesses are exclusively present in patients with $\operatorname{EoE}^{(15,18)}$, but it was present in $20 / 34$ biopsies in our study. Recently, a novel marker has been described, the autophagy related gene product 7 (ATG7), that has an accuracy of $82 \%$ in differentiating active EoE from EoE in remission and GERD ${ }^{(14)}$. It is important to note that all fragments with less than 15 eosinophils per hpf presented also other histological features, such as eosinophilic microabscesses, extracellular eosinophilic granules, surface disposition of eosinophils, epithelial desquamation and peripapillary eosinophilia. Therefore, the histological diagnosis of EoE should not rely only on eosinophilic density. Indeed, a new histological score (the EoE Specific Histologic Scoring System) has been proposed for disease assessment, and it includes several variables beyond eosinophilic counts, such as basal zone hyperplasia, eosinophil abscesses, surface epithelial alteration, dyskeratosis, dilated intercellular spaces and fibrosis ${ }^{(4)}$.

Only one patient presented $H$. pylori gastritis. Another group reported $7(7.8 \%) \mathrm{H}$. pylori infected patients among 89 patients with $\mathrm{EoE}^{(3)}$. It seems there is an inverse relationship between $H$. pylori and EoE, as well as with other allergic conditions ${ }^{(6)}$.

\section{CONCLUSION}

The eosinophilic infiltrate in EoE is focal, and multiples biopsies are required for the correct diagnosis. Other histologic findings may be useful if there is no intense eosinophilic infiltrate.

\section{Authors' contributions}

Carrasco AEAB: study conception and design, data acquisition, data analysis, data interpretation, manuscript drafting, critical revision. Machado RS: study conception and design, data acquisition, data analysis, data interpretation, manuscript drafting, critical revision. Patrício FRS: study conception and design, data acquisition, data analysis, data interpretation, manuscript drafting, critical revision. Kawakami E: study conception and design, data analysis, data interpretation, manuscript drafting, critical revision.

Carrasco AEAB, Machado RS, Patrício FRS, Kawakami E. Caracterização histopatológica da esofagite eosinofílica em crianças e adolescentes. Arq Gastroenterol. 2017;54(4):281-5.

RESUMO - Contexto - Esofagite eosinofílica é uma doença emergente caracterizada por infiltrado eosinofílico esofágico não responsivo a inibidores de bomba de prótons. Objetivo - Caracterizar os achados histopatológicos de uma coorte de crianças e adolescentes com diagnóstico de esofagite eosinofílica. Métodos - Estudo transversal conduzido em hospital terciário. Biópsias de terços proximal, médio e distal de 14 pacientes (idade mediana 7 anos) com diagnóstico de esofagite eosinofílica. Estudo morfométrico e variáveis histológicas analisadas em fragmentos de biópsias nos terços esofágicos: contagem de eosinófilos/CGA, grânulos eosinofílicos extracelulares, microabscessos eosinofílicos, disposição superficial de eosinófilos, descamação epitelial, eosinofilia peripapilar, hiperplasia da camada basal e alongamento de papilas. Resultados - Vários pacientes apresentaram aspecto macroscópico normal da mucosa esofágica à endoscopia $(6,42.8 \%)$, e a anormalidade mais comumente observada foi linhas verticais (7, $50 \%$ ) e exsudato branco (7, 50\%). Hiperplasia da camada basal foi observada em $88,8 \%, 100 \%$ e $80 \%$ das biópsias do terço proximal, médio e distal respectivamente $(P=0,22)$; contagem de eosinófilos nos terços variou de 0 a $\geq 50 / C G A$, grânulos eosinofílicos extracelulares (70\%-100\%), disposição superficial de eosinófilos (60\%-93\%), descamação epitelial (60\%-100\%), eosinofilia peripapilar (70\%-80\%), sem diferença estatística entre os terços esofágicos. Ausência de eosinofilia ocorreu raramente em terço distal (uma do distal, quatro do proximal, quatro do médio). Conclusão - Na ausência de hipereosinofilia, outros achados histopatológicos de inflamação eosinofílica estão presentes. A infiltração eosinofílica apresentou caráter focal, sugerindo-se a realização de múltiplas biópsias de diversos segmentos.

DESCRITORES - Doenças do esôfago. Dor abdominal. Esofagite eosinofílica. Eosinófilos. Esofagite péptica. 


\section{REFERENCES}

1. Aceves SS, Newbury RO, Dohil R, Schwimmer J, Bastian JF. Distinguishing eosinophilic esophagitis in pediatric patients: clinical, endoscopic, and histologic features of an emerging disorder. J Clin Gastroenterol. 2007;41:252-6.

2. Allen KJ, Heine RG. Eosinophilic esophagitis: trials and tribulations. J Clin Gastroenterol. 2011;45:574-82.

3. Assa'ad AH, Putnam PE, Collins MH, Akers RM, Jameson SC, Kirby CL, et al. Pediatric patients with eosinophilic esophagitis: an 8-year follow-up. J Allergy Clin Immunol. 2007;119:731-8

4. Collins MH, Martin LJ, Alexander ES, Boyd JT, Sheridan R, He H, et al. Newly developed and validated eosinophilic esophagitis histology scoring system and evidence that it outperforms peak eosinophil count for disease diagnosis and monitoring. Dis Esophagus. 2017;3:1.

5. Dellon ES, Gonsalves N, Hirano I, Furuta GT, Liacouras CA, Katzka DA. ACG clinical guideline: Evidenced based approach to the diagnosis and management of esophageal eosinophilia and eosinophilic esophagitis (EoE). Am J Gastroenterol. 2013;108:679-92.

6. Dellon ES, Peery AF, Shaheen NJ, et al. Inverse association of esophageal eosinophilia with Helicobacter pylori based on analysis of a US pathology database. Gastroenterology. 2011;141:1586-92.

7. Doyle LA, Odze RD. Eosinophilic esophagitis without abundant eosinophils? The expanding spectrum of a disease that is difficult to define. Dig Dis Sci. 2011;56:1923-5.

8. Furuta GT, Liacouras CA, Collins MH, Gupta SK, Justinich C, Putnam PE, et al. First International Gastrointestinal Eosinophil Research Symposium (FIGERS) Subcommittees. Eosinophilic esophagitis in children and adults: a systematic review and consensus recommendations for diagnosis and treatment. Gastroenterology. 2007;133:1342-63.

9. Genevay M, Rubbia-Brandt L, Rougemont AL. Do eosinophil numbers differentiate eosinophilic esophagitis from gastroesophageal reflux disease? Arch Pathol Lab Med. 2010;134:815-25.

10. Gonsalves N, Policarpio-Nicolas M, Zhang Q, Rao MS, Hirano I. Histopathologic variability and endoscopic correlates in adults with eosinophilic esophagitis. Gastrointest Endosc. 2006;64:313-9.

11. Kapel RC, Miller JK, Torres C, Aksoy S, Lash R, Katzka DA. Eosinophilic esophagitis: a prevalent disease in the United States that affects all age groups. Gastroenterology. 2008;134:1316-21.

12. Liacouras CA, Furuta GT, Hirano I, Atkins D, Attwood SE, Bonis PA, et al Eosinophilic esophagitis: updated consensus recommendations for children and adults. J Allergy Clin Immunol. 2011;128:3-20.

13. Mader AM, Alves MT, Kawakami E, Patrício FR. Reflux esophagitis in children: histological and morphometric study. Arq Gastroenterol. 2002;39:126-31.
14. Merves JF, Whelan KA, Benitez AJ, Muir AB, Furuta GT, Wang ML, et al. ATG7 Gene Expression as a Novel Tissue Biomarker in Eosinophilic Esophagitis. Am J Gastroenterol. 2016;111:151-3.

15. Mueller S, Neureiter D, Aigner T, Stolte M. Comparison of histological parameters for the diagnosis of eosinophilic oesophagitis versus gastro-oesophageal reflux disease on oesophageal biopsy material. Histopathology. 2008;53:676-84.

16. Noel RJ, Putnam PE, Rothenberg ME. Eosinophilic Esophagitis. N Engl J Med. 2004;351:940-1.

17. Odze RD. Pathology of eosinophilic esophagitis: what the clinician needs to know. Am J Gastroenterol. 2009;104:485-90.

18. Parfitt JR, Gregor JC, Suskin NG, Jawa HA, Driman DK. Eosinophilic esophagitis in adults: distinguishing features from gastroesophageal reflux disease: a study of 41 patients. Mod Pathol. 2006;19:90-6.

19. Pinheiro MI, de Góes Cavalcanti LP, Honório RS, de Alencar Moreno LH, Fortes $\mathrm{MC}$, da Silva CA. Eosinophilic esophagitis in brazilian pediatric patients. Clin Med Insights Pediatr. 2013;7:41-8.

20. Prasad GA, Alexander JA, Schleck CD, Zinsmeister AR, Smyrk TC, Elias RM, et al. Epidemiology of eosinophilic esophagitis over three decades in Olmsted County, Minnesota. Clin Gastroenterol Hepatol. 2009;7:1055-61.

21. Ravi K, Talley NJ, Smyrk TC, Katska DA, Kryzer L, Romero Y, et al. Low grade esophageal eosinophilia in adults: An unrecognized part of the spectrum of eosinophilic esophagitis? Dig Dis Sci. 2011;56:1981-6.

22. Remedios M, Campbell C, Jones DM, Kerlin P. Eosinophilic esophagitis in adults: clinical, endoscopic, histologic findings, and response to treatment with fluticasone propionate. Gastrointest Endosc. 2006;63:3-12

23. Rothenberg ME, Spergel JM, Sherrill JD, Annaiah K, Martin LJ, Cianferoni A, et al. Common variants at $5 \mathrm{q} 22$ associate with pediatric eosinophilic esophagitis. Nat Genet. 2010;42:289-91.

24. Rothenberg ME. Biology and treatment of eosinophilic esophagitis. Gastroenterology. 2009;137:1238-49.

25. Sá CC, Kishi HS, Silva-Werneck AL, Moraes-Filho JP, Eisig JN, Barbuti RC, et al. Eosinophilic esophagitis in patients with typical gastroesophageal reflux disease symptoms refractory to proton pump inhibitor. Clinics (Sao Paulo). 2011;66:557-61

26. Shah A, Kagalwalla AF, Gonsalves N, Melin-Aldana H, Li BU, Hirano I. Histopathologic variability in children with eosinophilic esophagitis. Am J Gastroenterol. 2009; 104:716-21

27. Spergel JM, Brown-Whitehorn TF, Beausoleil JL, Franciosi J, Shuker M, Verma $\mathrm{R}$, et al. 14 years of eosinophilic esophagitis: clinical features and prognosis. J Pediatr Gastroenterol Nutr. 2009;48:30-6.

28. Steiner SJ, Kernek KM, Fitzgerald JF. Severity of basal cell hyperplasia differs in reflux versus eosinophilic esophagitis. J Pediatr Gastroenterol Nutr. 2006;42:506-9. 